\title{
Penerapan Model Pembelajaran Problem Based Learning Untuk Meningkatakan Hasil Belajar Alat dan Mesin Pertanian Peserta Didik Kelas X ATP SMKN 6 Takalar
}

\section{The Application Of The Problem Based Learning Learning Model To Improve The Learning Outcomes Of Agricultural Tools and Machines Of Class X ATP Students At SMK Negeri 6 Takalar}

\author{
Haris Wandy, Program Studi Pendidikan Teknologi Pertanian, Fakultas Teknik, Universitas \\ Negeri Makassar.Email: Haris.wandy1994@gmail.com \\ Muhammad Rais, Program Studi Pendidikan Teknologi Pertanian, Fakultas Teknik, \\ Universitas Negeri Makassar. Email: Raismisi@gmail.com \\ Nurmila, Program Studi Pendidikan Teknologi Pertanian, Fakultas Teknik, Universitas \\ Negeri Makassar. Email: Noormila6@gmail.com
}

\begin{abstract}
ABSTRAK
Penelitian ini adalah penelitian tindakan kelas (Classroom Action Research) yang dilatar belakangi oleh rendahnya hasil belajar peserta didik yang disebabkan oleh kurangnya penerapan model pembelajaran yang variatif. Penelitian ini dimaksudkan untuk melihat peningkatan hasil belajar peserta didik pada mata pelajaran alat dan mesin pertanian kelas $\mathrm{X}$ ATP SMKN 6 Takalar. Subyek penelitian adalah peserta didik kelas X ATP SMKN 6 Takalar tahun pelajaran 2018/2019 dengan jumlah 17 orang yang dilakukan dalam dua siklus dan masing-masing siklus dilaksanakan dengan 4 kali pertemuan. Dari hasil penelitian ini memperlihatkan penerapam model Problem Based Learning berhasil meningkatkan meningkatkan hasil belajar peserta didik pada mata pelajaran alat dan mesin pertanian. Berdasarkan analisis kualitatif yang didapatkan dari lembar observasi keaktifan peserta didik menunjukkan menunjukkan aktifitas peserta didik pada siklus I dan siklus II mengalami peningkatan yang signifikan. Sedangkan analisis kuantitatif menunjukkan ketuntasan belajar klasikal pada tes awal yaitu 5,89\%, pada siklus I terjadi peningkatan sebesar 58,82\% sehingga ketuntasan secara klasikal menjadi $64,71 \%$ dan pada siklus II terjadi peningkatan hasil belajar sebesar 37,30\% sehingga ketuntasan secara klasikal menjadi $100 \%$.
\end{abstract}

Kata kunci: Metode, Hasil Belajar, Problem Based Learning, Alat dan Mesin Pertanian.

\section{ABSTRACT}

This research is a classroom action research (Classroom Action Research) which is motivated by the low learning outcomes of students caused by the lack of application of varied learning models. This study aims to determine the increase in learning outcomes of students in the subject of agricultural equipment and machine class X ATP SMKN 6 Takalar. The research subjects were students of class X ATP Takalar Vocational School 6 Takalar school year 2018/2019 with a total of 17 people carried out in two cycles and each cycle was carried out with 4 meetings. From the results of this study indicate the application of the Problem Based Learning model can improve student learning outcomes in the subject of agricultural equipment and machinery. Based on qualitative analysis obtained from the observation sheet of student activeness shows that the activities of students in cycle I and 
cycle II have increased significantly. While quantitative analysis shows classical learning completeness in the initial test is $5.89 \%$, in the first cycle an increase of $58.82 \%$ so that classical completeness becomes $64.71 \%$ and in the second cycle an increase in learning outcomes by $37.30 \%$ so that completeness classically be $100 \%$.

Keywords: Methods, Learning Outcomes, Problem Based Learning, Agricultural Tools and Machines.

\section{Pendahuluan}

Model pembelajaran memiliki peranan yang cukup besar terhadap proses belajar mengajar. Misalnya dapat digunakan sebagai landasan dalam melakukan program pembelajaran dengan baik. Namun, pada praktiknya tidak semua guru dapat menerapkan model pembelajaran. Kemampuan serta pengetahuan guru dalam bidang pengembangan yang minim menyulitkan guru untuk berinovasi lebih. Model pembelajaran yang dikemas dengan baik akan memberikan kontribusi dalam peningkatan hasil belajar peserta didik. Begitupula jika disampaikan dengan metode yang tidak tepat menyebabkan kemampuan peserta didik sulit dikembangkan. Keberhasilan pendidikan dapat dipengaruhi oleh beberapa aspek di antaranya, kapasitas sumber daya manusia yang dapat dilihat melalui proses belajar mengajar (Nurmila 2017)

Kunci keberhasilan dalam
penerapan gaya pembelajaran yaitu didapatkan hasil belajar yang meningkat dari sebelumnya, maka seorang pendidik diharapkan agar menerapkan model pembelajaran yang pas namun tetap memperhatikan kondisi peserta didik. Menurut Saraswati dkk., Pemilihan gaya pembelajaran yang pas adalah implementasi dari kreasi seorang pendidik agar peserta didik tidak bosan dalam memperoleh pelajaran. Sehingga, peserta didik mendapatkan suasana yang kondusif dalam proses belajarnya. Walaupun pada pelaksanaannya hampir disetiap sekolah menengah belum diaplikasikan model pembelajaran, sehingga materi yang harus disampaikan dengan penuh pengahayatan dari peserta didik belum terpahami dengan baik hanya sekedar penjelasan berbasis ceramah.

SMK Negeri 6 Takalar merupakan sekolah kejuruan yang dalam proses belajar mengajarnya masih menggunakan model pembelajaran trdisional menyebabkan peserta didik menganggap kurang mengerti tentang Alat dan Mesin Pertanian dan berdampak pada hasil belajar peserta didik terkhusus di kelas X ATP. Hal ini didapatkan pada saat peneliti melakukan observasi di SMK Negeri 6 Takalar. Berdasarkan hasil observasi menunjukkan bahwa masih banyak guru belum memanfaatkan penerapan model pembelajaran, dengan alasan kurang ahli dalam membuat konsep dan menerapkan model pembelajaran. Sehingga dari pengamatan peneliti menganalisis masalah pembelajaran terdapat pada model pembelajaran yang tidak tepat untuk mata pelajaran Alat dan Mesin Pertanian.

Menurut Agusprianti dkk., (2018) penetapan model pembelajaran yang tepat, tidak hanya mempertimbangkan keaktifan, potensi dan tingkat perkembangan peserta didik, tetapi juga bagaimana seorang pendidik memotivasi peserta didik. Sebagian besar peserta didik hanya menghafal pembelajaran yang diberikan 
dan tanpa memahami sehingga pada saat evaluasi peserta didik tidak mampu untuk menjawab pertanyaan yang disampaikan oleh pendidik dengan baik.

Keadaan tersebut menyebabkan perolehan belajar peserta didik pada mata pelajaran Alat dan Mesin Pertanian menghasilkan jumlah dibawah rata-rata kriteria ketuntasan minimal (KKM) yaitu 75. Hanya sekitar 9 peserta didik yang berhasil dengan nilai 76-100 dengan presentasi $50 \%$ tatkala parameter kesuksesan yang hendak didapatkan adalah $85 \%$ atau 15 orang jumlah peserta didik yang wajib sukses pada mata pelajaran tersebut dari total 18 peserta didik.

Salah satu cara yang bisa meningkatkan keaktifan dan perolehan belajar peserta didik dengan mata pelajaran Alat dan Mesin Pertanian pada kelas X ATP SMK Negeri 6 Takalar yaitu menggunakan gaya pembelajaran, yang tepatnya peneliti akan menerapkan model pembelajaran Problem Based Learning untuk menarik perhatian peserta didik agar bisa giat dan berenergi pada saat mengikuti pembelajaran. Peneliti memilih gaya pembelajaran Problem Based Learning untuk diterapkan pada mata pembelajaran Alat dan Mesin Pertanian karena gaya pembelajaran Problem Based Learning ini mempunyai keunggulan tersendiri dibandingkan dengan menggunakan metode pembelajaran yang lain. Sebagaimana hasil penelitian sebelumnya Choirun Nisak (2013) yang mengemukakan bahwa penerapan model pembelajaran Poblem Based Learning sangat layak sebagai model pembelajaran.

Model pembelajaran Poblem Based Learning ini sangat baik digunakan pada pelajaran Alat dan Mesin Pertanian karena model pembelajaran Poblem Based Learning ini mempunyai alur serta konsep yang menarik untuk meningkatkan kreatifitas pemikiran peserta didik. Penggunaan model pembelajaran Poblem Based Learning ini pada mata pelajaran Alat dan Mesin Pertanian cocok digunakan karena saat proses belajar mengajar berlangsung akan dijelaskan macammacam alat dan mesin pertanian serta memberikan sebuah gambaran masalah tekait alat dan mesin pertanian yang dimana peserta didik akan memusatkan perhatiannya dan akan memicu rasa penasaran terkait Alat dan Mesin Pertanian tanpa harus membayangkan lagi jika guru hanya menjelaskan saja.

Penelitian ini bertujuan untuk melihat pelaksanaan model pembelajaran Poblem Based Learning bisa menambahkan hasil belajar peserta didik kelas X ATP pada mata pelajaran Alat dan Mesin Pertanian di SMK Negeri 6 Takalar.

\section{Metode Penelitian}

Penelitian ini adalah penelitian tindakan kelas (Classroom Action Research) menggunakan tahapan pelaksanaan meliputi: perencanaan, pelaksanaan, evaluasi, dan refleksi secara berulang sesuai dengan siklus pembelajaran. Penelitian ini telah dilakukan di SMK Negeri 6 Takalar bertempat di Massamaturu Kec. Polombangkeng Utara, Kab. Takalar. Waktu penelitian dilakukan disemester genap Tahun Ajaran 2018/2019. Subjek penelitian adalah peserta didik kelas X ATP sejumlah 17 peserta didik. Tujuan penelitian ini adalah: Untuk memahami peningkatan hasil belajar peserta didik pada mata pelajaran alat dan mesin pertanian menggunakan gaya pembelajaran problem based learning di SMK Negeri 6 Takalar.

\section{Hasil Dan Pembahasan}

Pada siklus I dilakukan tes hasil belajar berformasi ulangan harian setelah penyampaian selama tiga kali pertemuan. 
Adapun file hasil perlakuan tes awal bisa diperhatikan pada tabel di bawah ini:

Tabel 1. Distribusi ketuntasan belajar alat dan mesin pertanian Peserta didik kelas $\mathrm{X}$ ATP SMK Negeri 6 Takalar pada siklus I

\begin{tabular}{cccc}
\hline Skor & Frekuensi & $\begin{array}{c}\text { Persentase } \\
(\%)\end{array}$ & Kategori \\
\hline $0-74$ & 6 & 35,29 & $\begin{array}{c}\text { Tidak } \\
\text { tuntas }\end{array}$ \\
$75-100$ & 11 & 64,71 & Tuntas \\
Jumlah & 17 & 100 & \\
\hline
\end{tabular}

Sumber : Hasil penjabaran data penelitian 2019

Berdasarkan Tabel 1 terlihat bahwa hasil ketuntasan belajar pada siklus I sebesar $64,71 \%$ atau 11 peserta didik dari 17 peserta didik berkedudukan dalam nominasi tuntas dan 35,29\% atau 6 peserta didik berkedudukan dalam nominasi tidak tuntas. Hal ini menunjukkan terdapat 6 peserta didik yang perlu remedial sebab belum menggapai kriteria ketuntasan belajar. Hal ini menunjukkan ketuntasan kelas secara klasikal belum terpenuhi yaitu $85 \%$ hingga harus diadakan tindakan lanjutan atau siklus II untuk mendapatkan kriteria ketuntasan klasikal yang telah ditentukan tersebut sehingga tujuan dari penelitian dapat tercapai yaitu adanya peningkatan hasil belajar peserta didik. (Nurmila 2017)

Tabel 2. Distribusi ketuntasan belajar alat dan mesin pertanian peserta didik kelas $\mathrm{X}$ ATP SMK Negeri 6 Takalar pada siklus II

\begin{tabular}{cccc}
\hline Skor & Frekuensi & $\begin{array}{c}\text { Persentase } \\
(\%)\end{array}$ & Kategori \\
\hline $0-74$ & 0 & 0 & $\begin{array}{c}\text { Tidak } \\
\text { tuntas }\end{array}$ \\
$75-100$ & 17 & 100 & Tuntas \\
Jumlah & 17 & 100 & \\
\hline Sumber : & Hasil penjabaran data penelitian \\
2019 & \multicolumn{3}{l}{}
\end{tabular}

Berdasarkan Tabel 2 di atas, terlihat bahwa hasil ketuntasan belajar pada siklus II sebesar $100 \%$ atau 17 peserta didik dari 17 peserta didik berkedudukan dalam nominasi tuntas dan $0 \%$ atau 0 peserta didik dari 17 peserta didik berkedudukan dalam nominasi tidak tuntas. Hal ini menandakan bahwa penelitian ini telah mencapai standar ketuntasan klasikal. Menurut Aulia dkk., (2016) berlandaskan tujuan yang hendak didapat, berlangsung peningkatan hasil belajar yang dikatakan berdasarkan kriteria hasil belajar mengenai ketuntasan kelas secara klasikal, yaitu $\geq 85 \%$ dari jumlah peserta didik yang tuntas, data dari hasil penelitian pada siklus II di atas dinyatakan tuntas karena peserta didik yang tuntas telah mencapai $100 \%$ sehingga penelitian ini tidak harus diteruskan pada siklus berikutnya.

\section{Simpulan}

Berdasarkan hasil analisis data dan pembahasan, dapat disimpulkan penerapan gaya pembelajaran problem based learning berhasil meningkatkan hasil belajar peserta didik pada mata pelajaran alat dan mesin pertanian di kelas X ATP di SMK Negeri 6 Takalar. Hal ini bisa diperhatikan dari ketuntasan belajar klasikal pada tes awal yaitu $5,89 \% \%$, pada siklus I terjadi peningkatan sebesar $58,82 \%$ sehingga ketuntasan secara klasikal menjadi $64,71 \%$ dan pada siklus II terjadi peningkatan hasil belajar sebesar 34,29\% sehingga ketuntasan secara klasikal menjadi $100 \%$.

\section{Daftar Pustaka}

Agusprianti. Muh. Rais, Amirah M. 2018. Model Cooperative Learning Type Complex Instruction (Ci) Untuk Meningkatkan Hasil Belajar Pada Mata Pelajaran Agribisnis Tanaman Sayuran Kelas Xi Atph Smk Negeri 4 Luwu. Jurnal 
Pendidikan Teknologi Pertanian, Vol. 4 (2018) : S132-S141

Aulia, N., Bakhrani R, Muh. Rais. 2016. Peningkatan Prestasi Belajar Peserta didik Pada Mata Pelajaran Mengendalikan Hama Tanaman Melalui Model Pembelajaran Berbasis Masalah Di Smk Negeri 6 Takalar. Jurnal Pendidikan Teknologi Pertanian, Vol. 2 (2016) : S70-S76

Aunurrahman. 2012. Belajar dan Pembelajaran. Bandung: Alfabeta.

Gunawan, Imam. 2013. Metode penelitian Kualitatif : Teori dan prakitik. Jakarta: Bumi Aksara.

Surabaya: Unesa Univrsity Press.

Nurmila, Husain, Nurmila. 2017. Penerapan Model Pembelajaran Kooperatif Tipe Numbered Heads Together (Nht) Untuk Meningkatkan Hasil Belajar Peserta Didik Agribisnis Tanaman Pangan Dan Hortikultura Smk Negeri 2 Soppeng. Jurnal Pendidikan Teknologi Pertanian, Vol. 3 (2017) : S211S220

Rusman. 2011.Model-model Pembelajaran mengembangkan Profesional Guru. Jakarta: Rajawali press.

Saraswati. Muh. Rais, Lahming. 2018. Penerapan Model Pembelajaran Kooperatif Tipe Two Stay Two Stray (Ts- Ts) Untuk Meningkatkan Prestasi Belajar Mata Pelajaran Teknologi Pengolahan Hasil Pertanian (Tphp) Kelas X Smk Negeri 3 Takalar. Jurnal Pendidikan Teknologi Pertanian, Vol. 4 (2018) : S184-S195

Slameto. 2003. Belajar dan Faktor-faktor yang mempengaruhinya. Jakarta: PT Rineka Cipta.

Suprijono. 2013. Cooperative Learning Teori dan Aplikasi PAIKEM. Yogyakarta: Pustaka Pelajar.
Trianto. 2010. Mengembangkan Model Pembelajaran Tematik. Jakarta: Pt. Prestasi Pustaka.

Trianto. 2013. Model pembelajaran Terpadu, konsep, strategidan implementasinya dalam kurikulum tingkat satuan pendidikan (KTSP). Jakarta: Bumi Aksara.

Zaky, A., Muh. Rais, Nurmila. 2018. Efektivitas Metode Pembelajaran Aktif Tipe Group To Group Exchange Dalam Meningkatkan Hasil Belajara Peserta didik Pada Mata Pelajaran Pemupukan Di Smkn 4 Jeneponto. Jurnal Pendidikan Teknologi Pertanian, Vol. 4 (2018) : S142-S149 
Halaman ini sengaja dikosongkan 